\title{
Cloning and Expression of Bbchit1 gene of Beauveria bassiana
}

\author{
Rajasekhar Pinnamaneni, P. Kalidas" ${ }^{\#}$ and K.R.S. Sambasiva Rao*
}

Department of Biotechnology, Acharya Nagarjuna University, Nagarjuna Nagar, Guntur, Andhra Pradesh, India

\begin{abstract}
Beauveria bassiana is a biocontrol agent which shows entomopathogenecity on insect pests especially the Lepidopterons invading the agriculturally important crops. The mode of infection is through the cuticle by degrading the chitin present on it which is enabled by the exochitinase enzyme of Bbchitl gene. A good quality DNA was isolated from Beauveria bassiana and amplified with specific primers to isolate the gene corresponding to Bbchitl which codes for the exochitinase enzyme that is responsible for pathogenesis. The Bbchitl gene of B. bassiana was transformed with the binary plasmid pBANF-bar-pAN-Bbchit1, in which the Bbchit1 gene was placed downstream of the constitutive gpd promoter, which was mediated by A. tumefaciens, and transformants were selected on the basis of herbicide resistance. Fifty herbicide resistant colonies were obtained and analyzed. The exochitinase produced by these transformants was observed maximum on the seventh day of inoculation in both which was $0.09 \mu \mathrm{mol} / \mathrm{ml} / \mathrm{min}$ for the purified fraction and $0.06 \mu$ $\mathrm{mol} / \mathrm{ml} / \mathrm{min}$ for the crude extract. The chitinolytic activity was observed maximum at $\mathrm{pH} 5$ and at temperature of $40^{\circ} \mathrm{C}$. The genetically modified pure form can be used in the production of transgenic plants and in bringing out commercial formulation for the control of Lepidopteran pests.
\end{abstract}

Keywords: Beauveria bassiana, Bbchit1.

\section{INTRODUCTION}

Biological control agents are being considered as alternatives to synthetic chemical insecticides that are known to have toxic effects on non-target organisms, including animals and humans [1,2]. Entomopathogenic fungi are key regulatory factors of insect populations in nature [3] and are attracting attention as biocontrol agents for insect pests [4]. However, mycoinsecticides constitute a very small percentage of the total insecticide market [5], even though entomopathogenic fungi are the only practical microbial control for insects that feed by sucking plant and animal juice and for the many acrid, lepidopteron and coleopteran pests which have no known viral or bacterial pathogens $[6$, 7]. Improvements in the effectiveness of mycoinsecticides may be obtained by optimizing the preparation and application of the inoculum [8]. Virulence of mycoinsecticides can also be achieved through the genetic modification $[9$, 10].

The insect cuticle, the first barrier against fungal pathogens, consists of a thin outer epicuticle, containing lipid and proteins, and a thick procuticle, consisting of chitin and proteins. Entomopathogenic fungi produce proteases, chitinases, and lipases which can degrade insect cuticle [11]. The entomopathogenic fungi M. anisopliae and Beauveria bassiana produce several chitinases [12-15], which may have a variety of different functions. Some of these chitinases are important cuticle-degrading enzymes and act synergistically with proteases to hydrolyze insect cuticle

*Address correspondence to this author at the Department of Biotechnology, Acharya Nagarjuna University, Nagarjuna Nagar, Guntur, Andhra Pradesh, India; Tel: 91-863-2346172; Fax: +91863-2293378;

E-mail: krssrao@gmail.com

"Directorate of Oil Palm Research (ICAR), Pedavegi, West Godavari District, Andhra Pradesh, India.
[16]. Overexpression of the Bbchitl gene from the entomopathogenic fungus Beauveria bassiana in transgenic $B$. bassiana can significantly enhance the virulence of $B$. bassiana for aphids. Insect bioassay results show significantly $50 \%$ lower lethal concentrations and $50 \%$ lethal times of the transformants overexpressing Bbchitl gene compared to the values for the wildtype strain, suggesting that overproduction of chitinase of Bbchitl can promote the infection efficiency of B. bassiana in aphids and accelerate infection.

In light of the importance of the Beauveria bassiana, a biocontrol agent the present work was carried out to study the selection of a suitable expression vector to carry Bbchit1 gene that expresses exochitinase responsible for pathogenesis.

\section{MATERIALS AND METHODS}

\section{Cloning of Bbchitl Gene}

\section{a. Isolation of DNA from Beauveria bassiana}

The DNA of Beauveria bassiana was prepared as per the protocol described by [17] with a slight modification.

B. bassiana mycelia were ground to a powder in a mortar under liquid nitrogen. Ten milligrams of powder were transferred to a microfuge tube and then, $300 \mathrm{ml}$ lysis buffer (100 mM Tris- $\mathrm{HCl} \mathrm{pH} 8.0,50 \mathrm{mM}$ EDTA, 3\% SDS) was added. The tube was incubated at $65^{\circ} \mathrm{C}$ for $1 \mathrm{hr}$ before 300 $\mathrm{ml}$ Tris-EDTA (TE)-saturated phenol/chloroform (1:1) was added. The mixture was then vigorously vortex and centrifuged at $12,000 \mathrm{rpm}$ for $20 \mathrm{~min}$. The supernatant was transferred to a new microfuge tube and then, 0.1 volume $3 \mathrm{M}$ Sodium acetate and 1 volume ice-cold isopropanol were added. The solution was mixed before incubation in ice for $30 \mathrm{~min}$. The DNA pellet was spun down at $12,000 \mathrm{rpm}$ for 20 min before being washed with $70 \%$ ethanol. The DNA 
pellet was dissolved in $100 \mathrm{ml} \mathrm{TE}$ buffer and then, at $37^{\circ} \mathrm{C}$ for $1 \mathrm{hr}$. The DNA was cleaned by phenol: chloroform: isoamyl alcohol (25:24:1) extraction, then vortexing, and centrifuging at 13,000 $\mathrm{rpm}$ for $5 \mathrm{~min}$. The top aqueous layer was transferred to a microfuge tube and re-extracted. The DNA was precipitated on ice by adding 0.1 volume $3 \mathrm{M}$ Sodium acetate and 1 volume ice-cold isopropanol. The pellet was spun down and dissolved in TE buffer as describe earlier. $4 \mathrm{ml} \mathrm{RNase}(1 \mathrm{mg} / \mathrm{ml})$ was added to remove RNA. After mixing, the tube was incubated.

\section{b. Amplification of Bbchit1 gene of Beauveria bassiana by} Polymerase Chain Reaction (PCR)

\section{Primers Used for Polymerase Chain Reaction}

\begin{tabular}{|c|c|}
\hline Primers & Sequence \\
\hline \hline Bbchitl-1 & $5^{\text {I-CAACATACCAATCATGGCTCCTTTTCTTCAAA-3 }}$ \\
\hline Bbchitl-2 & $5^{\mathrm{I}}$ - TTATTTTCGACTTTACAAGTACAATCCAT $-3^{\mathrm{I}}$ \\
\hline
\end{tabular}

The Bbchitl gene of Beauveria bassiana was amplified in a Master cycler gradient (Eppendorf, Germany). In Polymerase Chain Reaction, the specific primers Bbchit1-1 and Bbchit1-2 (Helini Biomolecules, Chennai) were used to amplify the genomic sequence of the open reading frame (ORF) of the gene.

PCR reactions contained $2 \mu \mathrm{g}$ B.bassiana DNA, 1 unit Taq DNA polymerase (Helini Biomolecules, Chennai), 2 pmol primers, $0.2 \mathrm{mM}$ dNTP, 1xPCR buffer, and deionized water to make the final volume to $50 \mathrm{ml}$. Thirty PCR cycles consisting of denaturation $\left(30 \mathrm{~s}\right.$ at $\left.95^{\circ} \mathrm{C}\right)$, annealing $(30 \mathrm{~s}$ at $\left.60^{\circ} \mathrm{C}\right)$, and extension $\left(120 \mathrm{~s}\right.$ at $\left.72^{\circ} \mathrm{C}\right)$ were performed. The PCR results were then checked in $1 \%$ agarose gel, and an expected band $(\sim 1 \mathrm{~kb})$ was excised, extracted and digested with restriction enzymes for subcloning.

\section{c. Agarose Gel Electrophoresis}

Required amount of agarose (w/v) was weighed and melted in $1 \mathrm{X}$ TBE buffer (0.9M Tris-borate, $0.002 \mathrm{M}$ EDTA, $\mathrm{pH}$ 8.2). Then, 1-2 $\mu 1$ ethidium bromide was added from the stock $(10 \mathrm{mg} / \mathrm{ml} \mathrm{H} 2))$. After cooling, the mixture was poured into a casting tray with an appropriate comb. The comb was removed after solidification and the gel was placed in an electrophoresis chamber containing $1 \mathrm{X}$ TBE buffer. The products were mixed with $6 \mathrm{X}$ loading buffer $(0.25 \%$ bromophenol blue, $0.25 \%$ xylene cyanol FF, $30 \%$ glycerol in water) at 5:1 ratios and loaded into the well. Electrophoresis was carried out at $60 \mathrm{~V}[18]$.

\section{d. Eluting DNA from Agarose Gel Fragments}

Ethidium bromide stained agarose gel was visualized under a transilluminator. The fragment of interest was excised with a clean razor blade. After removing the excess liquid, the agarose fragment was placed in the spin column. The tube was centrifuged at $5500 \mathrm{rpm}$ for not more than 45 seconds for the elution of DNA. The eluent was checked by running on an agarose gel and observed on a transilluminator for the presence of ethidium bromide stained DNA. The eluted DNA was used directly in manipulation reactions. This DNA fraction was subjected for sequencing (Helini Biomolecules, Chennai).

\section{e. DNA Manipulation}

The overexpression cassette located in pBANF-bar-pANBbchit1 was introduced into B. bassiana by using protocols [19]. The Bbchitl gene was introduced into multiple cloning sites into the BamHI site and EcoRI of the pAN52-1 vector. Then it was digested with S2 nuclease to remove the ATG translation start codon in the gpd promoter, and religated. Then the vector was subjected for the sequence analysis to examine the orientation of the insert and to confirm that the ATG had been successfully removed. There were two orientations of the multiple cloning sites within pAN52-1. After confirming that there was no mutant by sequence analysis, the Bbchitl open reading frame was excised from pGEM-T with EcoRI and SmaI, it was ligated into pBANF-bar-pANES to form pBANF-bar-pAN-Bbchit1.

\section{f. Transformation and Screening}

Transformants were selected for resistance to $60 \mathrm{~g}$ of the herbicide phosphinothricin per $\mathrm{ml}$. Wet mycelia $(2.5 \mathrm{~g})$ of herbicide resistant transformants were transferred from Potato Dextrose broth to basal salt medium supplemented with $2 \%$ glucose and $0.5 \%$ sodium nitrate was grown at $25 \pm 2{ }^{0} \mathrm{C}$ for 24 hours at $100 \mathrm{rpm}$. Higher chitinase activity should be detected in liquid cultures of the transformants which overproduced Bbchitl than in broth cultures of the wild-type strain. SDS-PAGE was employed to confirm the expression of Bbchitl and overexpression by assaying chitinase activity.

\section{Gene Expression Analysis}

To analyze the regulatory effect of glucose on the production of chitinase in the media containing colloidal chitin, the screened culture was transferred into potato dextrose broth suspended with $1 \%$ [wt/vol] colloidal chitin (HIMEDIA). After 24 hours, the samples were collected at 48-h intervals by filtration through Whatman filter paper number 5. The filtrates were lyophilized, dissolved in distilled water and desalted by using $75 \%$ Ammonium sulphate precipitation. The protein so obtained was centrifuged and the pellet obtained was dialysed. Twenty micrograms of protein was then subjected to SDS-Polyacrylamide gel electrophoresis.

\section{a. Chitinase Purification}

Culture fluid of cloned vector containing culture grown in basal salt medium containing $1 \%(\mathrm{wt} / \mathrm{vol})$ colloidal chitin for one week was filtered through Whatman filter paper number 5 and the filtrate was subjected to precipitation with ammonium sulphate $(75 \%, \mathrm{wt} / \mathrm{vol})$. The pellet was harvested by centrifugation and dissolved in $100 \mathrm{mM}$ Tris- $\mathrm{HCl}$ buffer ( $\mathrm{pH}$ 8.0). After dialysis against the same buffer, the crude extract was subjected to anion-exchange chromatography with a DEAE cellulose column (Helini Biomolecules, Chennai). After the column was washed with 3 column volumes of $20 \mathrm{mM}$ Tris- $\mathrm{HCl}$ buffer $(\mathrm{pH} \mathrm{7.8)}$, it was eluted with a $100-\mathrm{ml}$ linear gradient of $\mathrm{NaCl}(0$ to $1 \mathrm{M})$ in the washing buffer at a flow rate of $1 \mathrm{ml} / \mathrm{min}$. Fractions with chitinase activity were collected and concentrated against PEG 20,000 for further analysis.

\section{b. Analysis of Chitinase Enzyme of Beauveria bassiana by SDS-PAGE}

Protein samples $(50 \mu \mathrm{g})$ were diluted fivefold in electrophoresis sample buffer and subjected to $12.5 \%$ 
polyacrylamide gel containing $0.1 \%$ SDS. The medium ranged molecular weight marker (HELINI, Chennai) mixed with the sample buffer was also loaded in one of the wells. Electrophoresis was carried out at constant voltage of 75 volts. Gels were stained with Coomassie Brilliant Blue solution overnight and then destained. Protein bands with chitinolytic activity were detected using SDS-polyacrylamide gel containing $0.01 \%$ glycol chitin by the method previously described [14].

\section{c. Assay of Chitinase Activity}

Chitinase activity assay was performed as described by [20]. One unit of chitinase activity was defined as the amount of enzyme that released sugars equivalent to $1 \mu \mathrm{mol}$ of $N$-acetylglucosamine per/h at $37^{\circ} \mathrm{C}$.

\section{d. Factors Affecting the Activity of Chitinases}

The activity of the exochitinase enzyme was detemined at various $\mathrm{pH}$ starting from 4 to 9 and at various temperatures starting from $25^{\circ} \mathrm{C}$ to $60^{\circ} \mathrm{C}$ to assess its maximum activity.

\section{Virulence of Transformants}

To test the virulence of individual transformants, thirdinstar Leaf web formers feeding on Oil palm were used for bioassay. The larvae were sprayed with $10^{7}$ fungal spores $/ \mathrm{ml}$ and also with the crude extract. The excessive liquid on the insect body was removed with dry filter paper. The control larvae were treated with water plus $0.05 \%$ (v/v) Tween 80 . All the experimental and control larvae were fed on Oil palm leaves. The number of insects with normal body colour and the number of dead insects were recorded every $8 \mathrm{~h}$.

\section{RESULTS AND DISCUSSION}

\section{Cloning of Bbchit1 Gene}

\section{a. DNA Extraction, Purification and Quantification}

The DNA pellet was white, thick thread like mass. This DNA obtained was further quantified by spectrophotometry and agarose gel electrophoresis. It was observed that Beauveria bassiana DNA fragments were observed to emit orange fluoroscence under UV lamp. The $\mathrm{A}_{260} / \mathrm{A}_{280}$ ratio for Beauveria bassiana DNA was found to be 1.9 spectrophotometrically. This study revealed the method adopted for extraction; purification and quantification of DNA were found to be suitable for molecular studies of Beauveria bassiana.

\section{b. Amplification of Bbchit1 Gene of Beauveria bassiana by Polymerase Chain Reaction (PCR) and Sequencing}

The amplified fragment of DNA when analyzed by agarose gel electrophoresis indicates that it was of good quality. Then the sample was eluted and sequenced, the sequence of the amplified product was as follows.

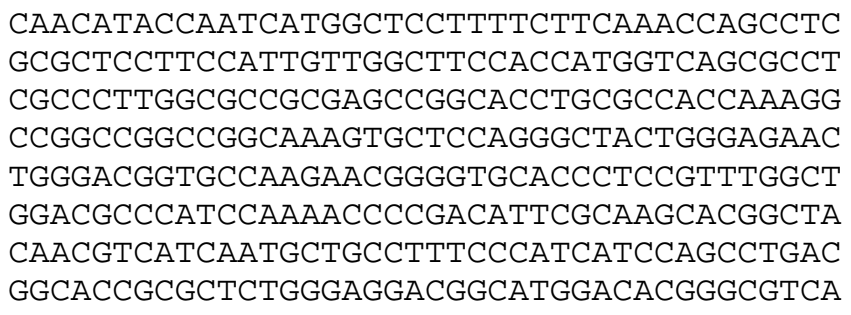

AGGTGGCGAGCCCGGCCGACATGTGCGAGGCCAAGGCAGC AGGTGCCACCATCTTGATGTCGATTGGCGGTGCTACTGCG GCCATTGACCTGAGCTCGTCGGCTGTGGCTGACAAGTTTG TCTCGACCATTGTGCCGATTCTGAAAAAGTACAACTTTGA CGGCATTGATATCGACATTGAATCCGGCCTCACAGGCAGC GGAAACATAAACACCCTGTCCACCTCGCAGACCAACCTGA TTAGAATCATTGACGGCGTTCTCGCGCAGATGCCCGCCAA CTTTGGCTTGACCATGGCGCCAGAGACTGCCTACGTTACC GGTGGGACTATTACGTACGGATCAATCTGGGGCTCTTACC TCCCCATTATCAAAAAGTACCTGGACAATGGTCGTCTCTG GTGGCTCAACATGCAGTACTACAATGGCGAAATGTACGGC TGCTCCGGCGACTCGCACAAGGCCGGTACTGTCGAAGGAT TCATTGCTCAGACCGACTGCCTGAACAAGGGACTTAGTAT TCAGGGCGTGACAATCACGATTCCCTATGACAAGCAAGTG CCTGGCCTTCCTGCCCAGCCTGGGGCTGGCGGCGGCCACA TGTCCCCGTCCAACGTGGCGCAAGTTCTCTCCCACTACAA GGGCGCTTTGAAGGGATTGATGACTTGGTCTCTGAACTGG GACGGCTCCAAGAATTGGACATTTGGCGACAATGTCAAGG GGACTTTGGGGACTGCGTAATAAAAGCTGAAATGTTCATG TTAGGTA

The sequence of the amplified product contains 1087 bases (Fig. 1). The sequence when made a BLAST hit, has evidenced that it was having an open reading frame coding for the enzyme exochitinase encoded by 1051 bases. The sequence of the exochitinase enzyme was deposited in NCBI Database and its GI: 194025184. Hence, this gene was further used for cloning in a suitable vector for the gene expression studies.

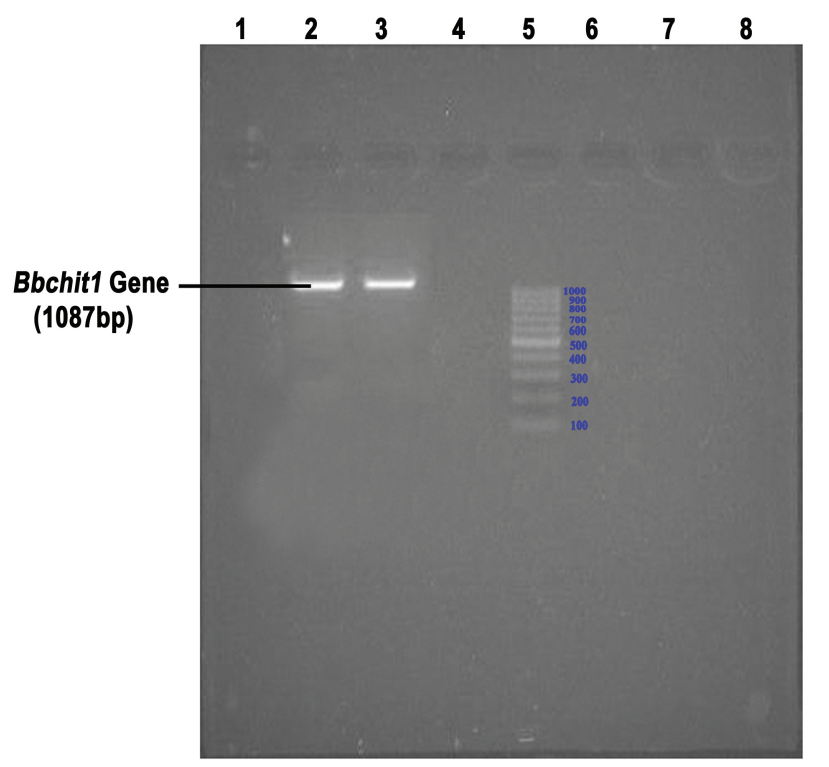

Fig. (1). Agarose gel showing the amplified gene product. Well 2,3: Amplified PCR Product of Bbchit1.

Well 5: DNA Ladder of $1 \mathrm{~kb}$.

c. Construction and Characterization of B. bassiana Transformants Overproducing Exochitinase of Bbchit1

B. bassiana was transformed with the binary plasmid pBANF-bar-pAN-Bbchit1 (Fig. 2). The Bbchit1 gene was placed downstream of the constitutive gpd promoter, which 
was mediated by $A$. tumefaciens. The transformants were selected on the basis of herbicide resistance. Fifty herbicide resistant colonies were obtained and analyzed in basal salt medium supplemented with glucose that repressed native Bbchit1 production. The chitinase produced by these transformants was analysed further by isolating the protein in pure form and assaying its enzyme activity.

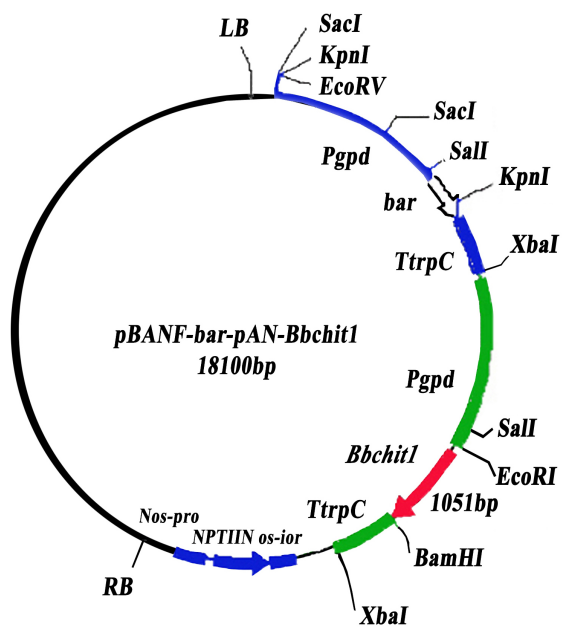

Fig. (2). Vector with the cloned insert of Bbchit1 gene.

Pgpd, A. nidulans gpd promoter.

bar, the sequence encoding the phosphinothricin acetyltransferase gene.

TtrpC, terminator sequence of the $A$. nidulans $\operatorname{Trp} C$ gene.

Nos-pro, A.tumefaciens Nos gene promoter.

Nos-ter, A. tumefaciens Nos gene terminator.

NPTII, kanamycin resistance gene.

LB, left border.

$\mathrm{RB}$, right border.

\section{Gene Expression Analysis}

The enzyme exochitinase was precipitated by saturating with $35 \%$ and $70 \%$ Ammonium sulphate and the exochitinase enzyme was obtained in $70 \%$ fraction. This enzyme

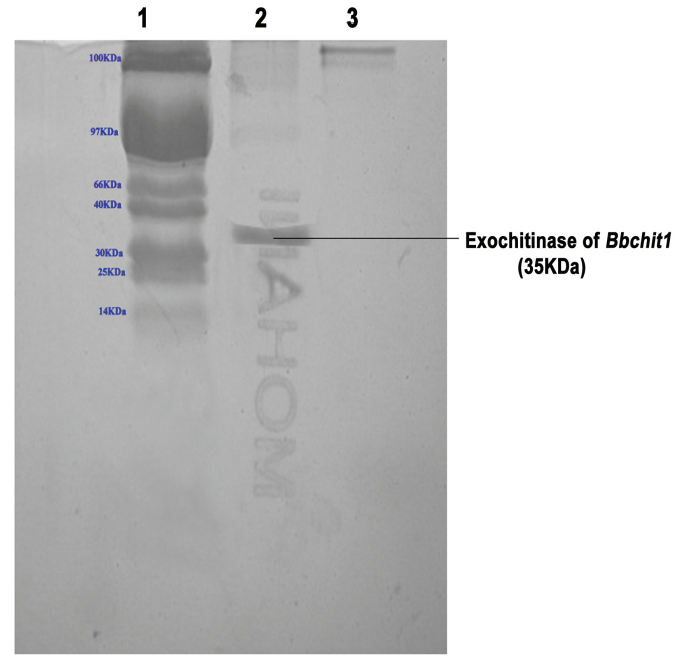

Fig. (3). SDS-PAGE showing the purified chitinase.

Well 1: $100 \mathrm{KDa}$ Protein Marker.

Well 2: Exochitinase of Bbchit1. fraction upon subjecting to dialysis, the pure fraction was obtained. This pure fraction was further purified by Anion exchange chromatography and the eluent was collected. This eluent was checked by SDS-Polyacrylamide gel electrophoresis and the band corresponding to $35 \mathrm{KDa}$ denotes that the eluent was exochitinase. This was in accordance with the findings of Trudel and Asselin [21] (Fig. 3).

\section{a. Chitinase Activity Shown by Culture Filtrates}

The chitinase activity of culture filtrate in purified form and the crude form at all the days of inoculation to 15 days was carried out to assess its chitinolytic activity. It was observed that maximum chitinolytic activity was observed on the seventh day of inoculation in both which was $0.09 \mu$ $\mathrm{mol} / \mathrm{ml} / \mathrm{min}$ for the purified fraction and $0.06 \mu \mathrm{mol} / \mathrm{ml} / \mathrm{min}$ for the crude extract. It was noticed that with the increase in time of incubation, the activity increased rapidly and with the further increase in the time of incubation, the activity fell down (Table 1; Fig. 4).

Table 1. Enzyme Activity of Chitinase (Crude and Purified)

\begin{tabular}{|c|c|c|}
\hline \multirow{2}{*}{ Days } & \multicolumn{2}{|c|}{ Chitinase Activity $(\boldsymbol{\mu ~ m o l} / \mathbf{m l} / \mathbf{m i n})$} \\
\cline { 2 - 3 } & Purified & Crude \\
\hline \hline 1 & 0.007 & 0.005 \\
\hline 2 & 0.009 & 0.006 \\
\hline 3 & 0.02 & 0.009 \\
\hline 4 & 0.03 & 0.01 \\
\hline 5 & 0.06 & 0.03 \\
\hline 6 & 0.07 & 0.04 \\
\hline 7 & 0.09 & 0.06 \\
\hline 8 & 0.06 & 0.05 \\
\hline 9 & 0.05 & 0.03 \\
\hline 10 & 0.05 & 0.02 \\
\hline 11 & 0.04 & 0.02 \\
\hline 12 & 0.03 & 0.01 \\
\hline 13 & 0.02 & 0.008 \\
\hline 14 & 0.02 & \\
\hline
\end{tabular}

\section{b. Chitinase Activity at Different pH}

The chitinolytic activity of culture filtrates of Beauveria bassiana at varied $\mathrm{pH}$ conditions were carried out to assess its chitinolytic activity. It was observed that maximum chitinolytic activity was observed at $\mathrm{pH} 5$ which was $0.06 \mu$ $\mathrm{mol} / \mathrm{ml} / \mathrm{min}$. Its maximum chitinolytic activity was observed at the mild acidic range and its activity decreased as the bacicity was increased. This could be concluded from the observations of $\mathrm{pH}$ levels 4 to 9 . Altogether, it gives the impression that the test organism was capable to show chitinolytic activity maximum at pH level 5 (Table 2; Fig. 5). 


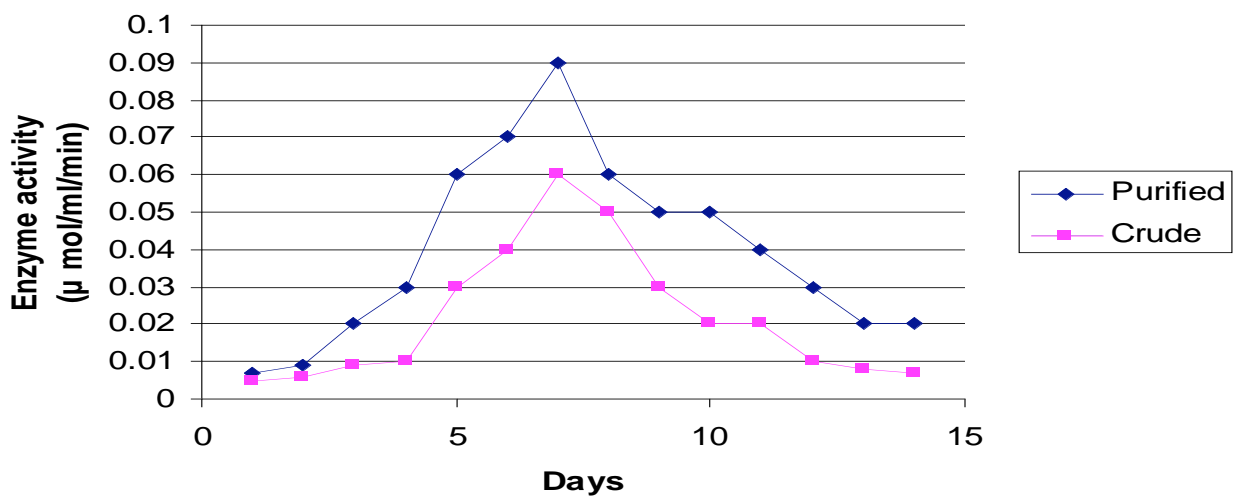

Fig. (4). Chitinase enzyme activity. Peaks showing Chitinase activity of Purified and Crude forms.

Table 2. Enzyme Activity of Chitinase at Various pH

\begin{tabular}{|c|c|}
\hline $\mathbf{p H}$ & Chitinase Activity $(\boldsymbol{\mu} \mathbf{~ m o l} / \mathbf{m l} / \mathbf{m i n})$ \\
\hline \hline 4 & 0.04 \\
\hline 5 & 0.06 \\
\hline 6 & 0.05 \\
\hline 7 & 0.03 \\
\hline 8 & 0.01 \\
\hline 9 & 0.01 \\
\hline
\end{tabular}

\section{c. Chitinase Activity at Different Temperatures}

The chitinolytic activity of culture filtrate of Beauveria bassiana at varied temperature conditions were carried out to assess its chitinolytic activity. It was observed that maximum chitinolytic activity was observed at temperature $40^{\circ} \mathrm{C}$ which was $0.05 \mu \mathrm{mol} / \mathrm{ml} / \mathrm{minute}$. Its chitinolytic activity was observed to increase from $25^{\circ} \mathrm{C}$ to $40^{\circ} \mathrm{C}$ and its activity again tends to decrease as the temperature was increased. This could be concluded from the observations of temperature levels $25^{\circ} \mathrm{C}$ to $60^{\circ} \mathrm{C}$. Altogether, it gives the impression that the test organism was capable to show chitinolytic activity maximum at temperature of $40^{\circ} \mathrm{C}$ (Table 3; Fig. 6).

\section{Virulence of Transformants}

To determine the virulence of the transformants, we used third-instar Leaf web formers feeding on Oil palm as the

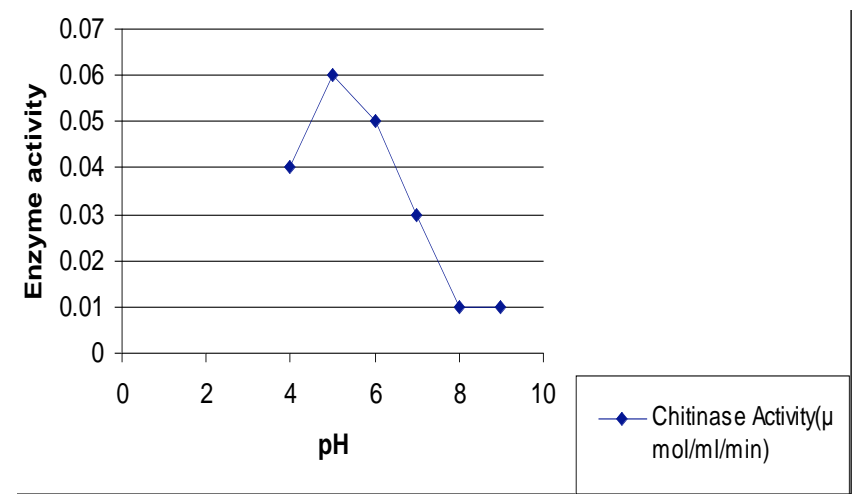

Fig. (5). Effect of pH on the Chitinase activity. Peak showing Chitinase activity at varied $\mathrm{pH}$. experimental insect. All transformants displayed the same degree of virulence as Beauveria bassiana. However, the cuticles of the larvae treated with purified enzyme extract began to whiten $24 \mathrm{~h}$ after the inoculation while the ones treated with Beauveria bassiana started to whitening $48 \mathrm{~h}$ after the inoculation. The data demonstrated that purified enzyme extract had greater virulence for the Leaf web formers feeding on Oil palm than the wild-type parental control.

Table 3. Enzyme Activity of Chitinase at Various Temperatures

\begin{tabular}{|c|c|}
\hline Temperature $\left({ }^{\circ} \mathrm{C}\right)$ & Chitinase Activity $(\mu \mathrm{mol} / \mathrm{ml} / \mathrm{min})$ \\
\hline 25 & 0.025 \\
\hline 30 & 0.03 \\
\hline 40 & 0.05 \\
\hline 50 & 0.02 \\
\hline 60 & 0.008 \\
\hline
\end{tabular}

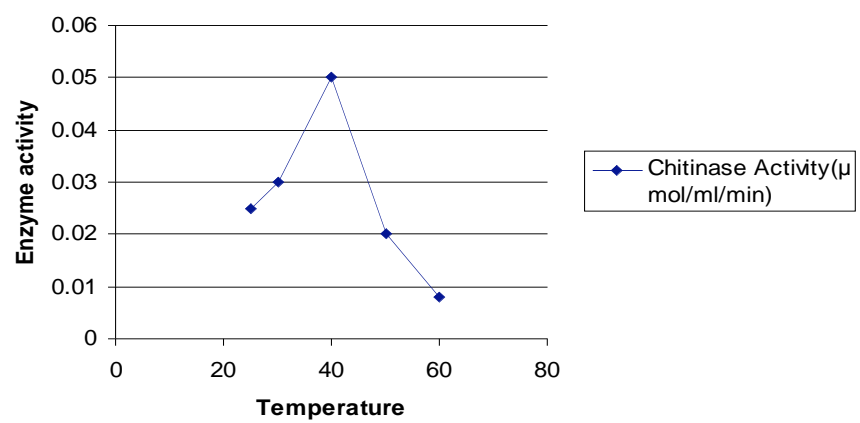

Fig. (6). Effect of temperature on the Chitinase activity. Peak showing Chitinase activity at varied Temperature.

\section{CONCLUSION}

A chitinase gene from $B$. bassiana was isolated from its genomic DNA by PCR. This gene was successfully cloned and expressed. The study revealed that Beauveria bassiana can be used as an effective biocontrol agent. The genetically modified form is more effective in expressing pathogencity as the exochitinase activity was maximum compared to that of crude extract and it can be used for the production of 


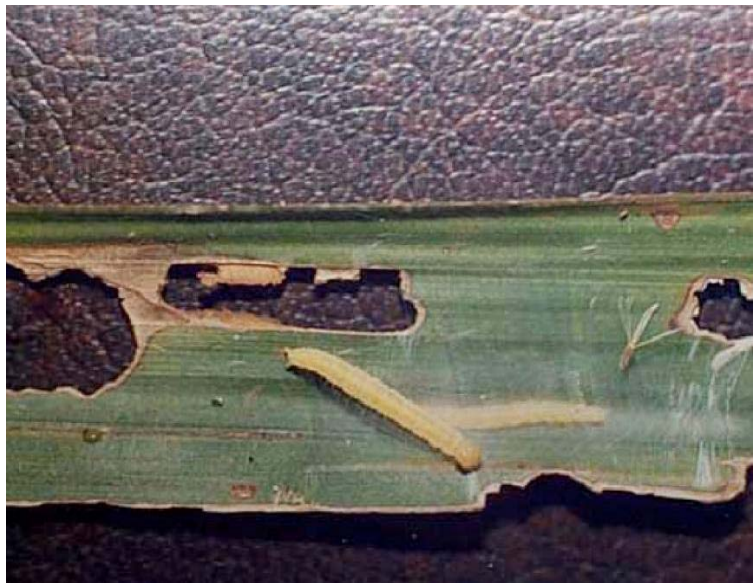

$\mathbf{a}$

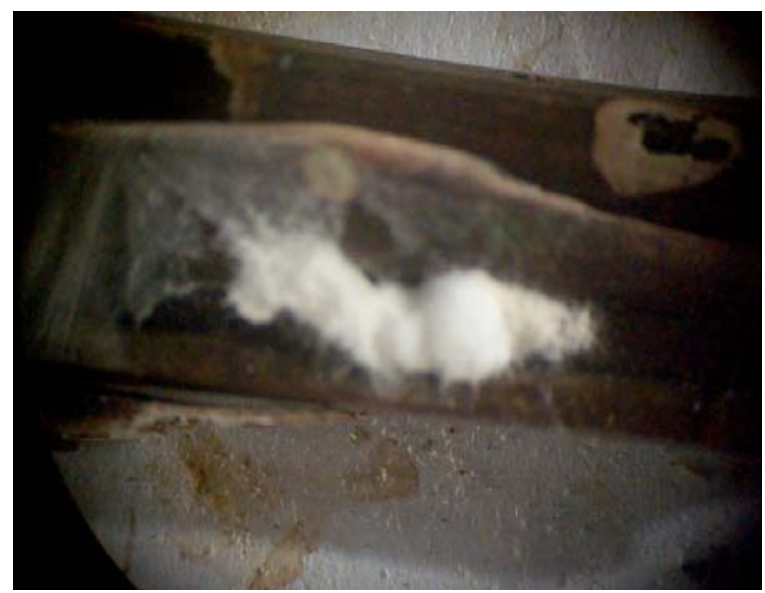

b

Fig. (7). a. Healthy Leaf web former. b. Infected Leaf web former.

transgenic plants and also in bringing a commercial formulation in a purified form of this pathogenic fungus that can be effectively used for the control of lepidopterans. Thus, the described transformation method is of great significance for manipulating the genetic make-up of the organism for improvement of its entomopathogenicity and also could provide a powerful tool for studying the functions of $B$. bassiana genes in general.

However, we realize that additional experiments are needed to demonstrate that the changes in morphology, growth characteristics, and virulence observed with purified enzyme extract are indeed due to the insertion of the T-DNA.

\section{REFERENCES}

[1] Bidochka MJ. Monitoring the fate of biocontrol fungi, In Butt TM, Jackson C, Magan N, Eds., Fungi as biocontrol agents. CABI, United Kingdom: Wallingford, Oxon 2001; pp. 193-218.
[2] St. Leger RJ, Joshi L, Bidochka MJ and Roberts DW. Construction of an improved mycoinsecticide overexpressing a toxic protease. Proc Natl Acad Sci USA 1996; 93:6349-4.

[3] Charnley AK. Entomopathogenic fungi and their role in pest control. In Wicklow DT, Soderstrom BE, Eds. The Mycota IV environmental and microbial relationships. Germany: Berlin, Springer 1997; pp. 185-201.

[4] Clarkson JM, Charnley AK. New insights into the mechanisms of fungal pathogenesis in insects. Trends Microbiol 1996; 4:197-203.

[5] St. Leger RJ and Screen SE. Prospects for strain improvement of fungal pathogens of insects and weeds. In Butt TM, Jackson C, Magan N, Eds. Fungi as biocontrol agents. CABI, United Kingdom: Wallingford, Oxon, 2001; pp. 219-237.

[6] Hajek AE, St. Leger RJ. Interactions between fungal pathogenesis and insect hosts. Annu Rev Entomol 1994; 39: 293-322.

[7] St. Leger RJ, Joshi L, Bidochka MJ, Rizzo NW, Roberts DW Characterization and ultrastructural localization of chitinases from Metarhizium anisopliae, M. flavoviride, and Beauveria bassiana during fungal invasion of host (Manduca sexta) cuticle. Appl Environ Microbiol 1996; 62: 907-912.

[8] Prior C. Discovery and characterization of fungal pathogens for locust and grasshopper control. In Lomer CJ, Prior C, Eds. Biological control of locust and grasshopper. CABI, United Kingdom: Wallingford, Oxon 1992; pp. 159-180.

[9] St. Leger RJ, Roberts DW. Engineering improved mycoinsecticides. Trends Biotechnol 1997; 15: 83-85.

[10] Wood HA. Development and testing of genetically improved baculovirus insecticides. In Shuler ML, Wood HA, Granados RR, Hammer DA, Eds. Baculovirus expression systems and biopesticides. New York, NY, Wiley 1995; pp. 91-102.

[11] Charnley AK, St. Leger RJ. The role of cuticle-degrading enzymes in fungal pathogenesis in insects. In Cole GT, Hoch HC, Eds. The fungal spore and disease initition in plants and animals. New York Plenum Press 1991; pp. 267-87.

[12] Bogo MR, Rota CA, Pinto Jr H, et al. A chitinase encoding gene (chit1 gene) from the entomopathogen Metarhizium anisopliae: isolation and characterization of genomic and full-length cDNA. Curr Microbiol 1998; 37: 221-225.

[13] Kang SC, Park S and Lee DG. Isolation and characterization of a chitinase cDNA from the entomopathogenic fungus, Metarhizium anisopliae. FEMS Microbiol Lett 1998; 165:267-271.

[14] St. Leger RJ, Staples RC and Roberts DW. Entomopathogenic isolates of Metarhizium anisopliae, Beauveria bassiana. J Invertebr Pathol 1993; 61: 81-84.

[15] Screen SE, Hu G, Leger RJ. Transformants Aspergillus flavus produce multiple extracellular chitinase isozymes, of Metarhizium anisopliae sf. anisopliae overexpressing chitinase from Metarhizium anisop. Magan N, Ed. Fungi as biocontrol agents. CABI, UK: Wallingford, Oxon 2001.

[16] St. Leger RJ, Cooper RM, Charnley AK. Cuticle degrading enzymes of entomopathogenic fungi: regulation of production of chitinolytic enzymes. J Gen Microbiol 1986; 132: 1509-1517.

[17] Reader U, Broda P. Rapid preparation of DNA from filamentous fungi. Lett Appl Microbiol 1985; 1: 17-20.

[18] Sambrook J, Fritsch EF, Maniatis T. Molecular cloning: A laboratory manual. New York: Cold Spring Harbor Laboratory 1989.

[19] Fang W, Bo L, Yuehua X, et al. Cloning of Beauveria bassiana chitinase gene Bbchitl and its application to improve fungal strain virulence. Appl Environ Microbiol 2005; 71: 363-370.

[20] Miller GL. Use of dinitrosalicylic acid reagent for determination of reducing sugars. Anal Chem1959; 31: 426-428.

[21] Trudel J, Asselin A. Detection of chitinase activity after polyacrylamide gel electrophoresis. Anal Biochem 1989; 178: 362366.

(C) Pinnamaneni et al.; Licensee Bentham Open.

This is an open access article licensed under the terms of the Creative Commons Attribution Non-Commercial License (http://creativecommons.org/licenses/by-nc/3.0/) which permits unrestricted, non-commercial use, distribution and reproduction in any medium, provided the work is properly cited. 